\title{
Biofilm formation of Candida Spp. isolated from the vagina and antibiofilm activities of lactic acid bacteria on the these Candida Isolates
}

\author{
Merih Kıvanç ${ }^{1}$, Sevda $\mathrm{Er}^{2}$
}

1. Department of Biology, Faculty of Sciences, Eskisehir Technical University, 26470, Eskisehir, Turkey.

2. Pharmacy Services Program, Yunus Emre Vocational School of Health Services, Anadolu University, 26470, Eskisehir, Turkey.

\begin{abstract}
Background: In this study, it was aimed to investigate the effects of bacterial cells and cell-free filtrates of Lactobacillus acidophilus 8MR7 and Lactobacillus paracasei subspecies paracasei 10MR8 on the biofilm formation of 3 Candida tropicalis, 3 C. glabrata and 12 C. albicans isolated from the vagina and identified their virulence factors.

Methods: Haemolytic activities esterase activities, and phospholipase activities as virulence factors of Candida strains were determined. Biofilm formations of these isolates were determined by Congo Red agar and microtitration plate method. Antibiofilm activities of bacterial cells and cell-free filtrates of L. acidophilus 8MR7 and L. paracasei subspecies paracasei 10MR8 on Candida isolates were determined by the microtitration plate method.

Results: Bacterial cells of L. acidophilus 8MR7 and L. paracasei subspecies paracasei 10MR8 were not very effective in the inhibition of biofilm, whereas it has been observed that the cell-free filtrates of these bacteria inhibit the formation of biofilms of Candida strains. Although the main mechanism for inhibiting the formation of Candida spp. biofilm is the competition for adhesion, it is concluded that the substances contained in the cell-free filtrates of lactic acid bacteria are also important. Conclusion: These isolates promise hope as potential bacteria that can be used for anti-adhesion purposes in health-care materials.
\end{abstract}

Keywords: Lactobacillus acidophilus; L. paracesei subspecies paracesei; vagina; biofilm.

DOI: https://doi.org/10.4314/ahs.v20i2.12

Cite as: Kivanc M, ErS. Biofilm formation of Candida Spp. isolated from the vagina and antibiofilm activities of lactic acid bacteria on the these Candida Isolates. Afri Health Sci. 2020; 20(2): 641-648. https:// doi.org/10.4314/ abs.v20i2.12

\section{Introduction}

The human microbiome colonized in the human body are composed of numerous microorganisms. Different microbial communities have been located in the vagina, mouth, skin, gastrointestinal tract, nose, urethra and other parts of the body ${ }^{1}$. Besides, the Candida species are also found in the normal microbiome of human especially they usually colonize on the skin and mucous membranes. Besides, Candida species are one of the

\section{Corresponding author: \\ Merih Kıvanç, Eskisehir Technical University, Faculty of Science Department of Biology 26470 Eskisehir, TURKEY \\ Tel:+90 2223350580 / 4725 \\ Fax:+90 2223204910 \\ e-mail:mkivanc@eskisehir.edu.tr}

most common pathogens in humans. They cause a wide spectrum of disease ranging from non-invasive superficial infections to infections involving the deep tissues.

Biofilm is a collection of microorganisms that are embedded in the exopolysaccharide matrix and are irreversibly attached to each other and to a surface. The structure and composition of Candida spp. biofilm can vary according to various environmental conditions. This reduces the success of the treatment. Several proposals have been made to prevent this in biofilm-forming Candida species isolates.

Lactobacilli are dominant in the vaginal microbiome of a healthy woman ${ }^{2}$. Lactobacilli play an important role in the protection of normal vaginal microbiome, inhibiting development of pathogenic and opportunistic organisms ${ }^{3}$. They have the properties such as tolerance to acid and bile salts, adhesion to the human intestinal mucosa, temporary colonization of the human gastro- 
intestinal tract, production of antimicrobial agents ${ }^{4}$. Lactic acid bacteria inhibit development of pathogen microorganisms by producing organic acids such as lactic acid, hydrogen peroxide, bacteriocin or bacteriocin-like substances. They compete with pathogens for food and colonization. Besides, these bacteria also have benefits such as stimulation of the immune system, lowering of serum cholesterol level, and reduction of cancer risk. Recently, several important biological functions of some lactic acid bacteria such as anti-aging and anti-oxidant activities have been revealed ${ }^{5}$.

In the present study, it was determined the biofilm formations in vitro conditions of 18 Candida spp. isolates isolated from the vagina and investigate the inhibition effects of Lactobacillus acidophilus 8MR7 and Lactobacillus paracasei subspecies paracasei $10 \mathrm{MR} 8$ on the biofilm formation of Candida spp.

\section{Materials and methods \\ Materials \\ Microorganisms}

In this study, Lactobacillus acidophilus $8 \mathrm{MR} 7$ and L. paracesei subspecies $10 \mathrm{MR} 8$ and 18 Candida spp. (3 C. tropicalis, 3 C. glabrata, 12 C. albicans) that isolated from the vagina of healthy women and identified by the API-CHL 50 test and the MALDI-TOF Mass Spectrometry Technique in another study were used. Bacteria and Candida isolates were incubated on the de Man, Rogosa, and Sharpe (MRS) agar and Sabouraud dextrose agar (SDA) at $37^{\circ} \mathrm{C} 5 \% \mathrm{CO} 2$ for $48 \mathrm{~h}$ and at $37^{\circ} \mathrm{C}$ for $48 \mathrm{~h}$, respectively.

\section{Methods}

\section{Determination of hemolytic activity}

For the determination of hemolytic activity, the Candida spp. isolates were incubated on the sheep blood agar at $37^{\circ} \mathrm{C}$ for $48 \mathrm{~h}$. Following incubation, beta hemolytic activity around the colony was determined by the existence of light-transmitting transparent zone, and alpha hemolytic activity was determined by the presence of dark green reproduction ${ }^{6}$.

\section{Determination of esterase activity}

Candida isolates were allowed to incubate for $48 \mathrm{~h}$ at $37^{\circ} \mathrm{C}$ in Sabouraud dextrose broth (SDB). After the concentrations of Candida isolates were adjusted to $10^{7}$ cfu / $\mathrm{mL}$ in $0.85 \%$ physiological saline following the incubation, $5 \mu \mathrm{L}$ of each culture was added dropwise to each culture on tween 80 agar medium. The petri dishes were incubated at $37^{\circ} \mathrm{C}$ for 10 days and after the incubation, the zone formation around the colony was examined. The experiment was performed in duplicate manner ${ }^{7}$.

\section{Phospholipase activity}

$10 \mu \mathrm{L}$ of yeast culture (adjusted to $10^{8} \mathrm{cfu} / \mathrm{mL}$ ) inoculated on egg yolk agar. Plates incubated for 4 days at $37^{\circ}$ C. After incubation, zone formation around the colony was measured. The experiment was performed in duplicate manner ${ }^{8}$. It was considered that $\mathrm{Pz}$ (phospholipase activity) $<0.70(++++)$ was very strong, $\mathrm{Pz}$ $=0.70-0.79(+++)$ strong, $\mathrm{Pz}=0.80-0.89(++)$ poor, and $\mathrm{Pz} \geq 1(-)$ weak.

\section{Determination of antifungal activities of lactic acid bacteria}

Antifungal activity against Candida spp. isolates of $\mathrm{L}$. acidophilus 8MR7 and L. paracesei subspecies paracasei 10MR8 was determined by the duplicate agar method. $5 \mu \mathrm{L}\left(10^{8} \mathrm{cfu} / \mathrm{mL}\right)$ of lactic acid bacteria culture was incubated dropwise on MRS agar (de Man, Rogosa, and Sharpe agar) at $35^{\circ} \mathrm{C} 5 \% \mathrm{CO} 2$ for $48 \mathrm{~h}$. After incubation, Candida spp. isolates (105cfu / mL) growing in the SDB was inoculated with Sabouraud dextrose semi-solid agar. After the semi-solid agar was thoroughly mixed, $7 \mathrm{~mL}$ of the solution was poured slowly onto the surface of the petri dishes containing the lactic acid bacteria. The petri dishes were allowed to incubate at $37^{\circ} \mathrm{C}$ for $48 \mathrm{~h}$. After incubation, the zone diameters around the lactic acid bacteria were measured and recorded9.

\section{Determination of biofilm formation}

The experiment was carried out in duplicate manner. The biofilm formation of the isolates was determined on Congo red agar and by the microtitration plate method.

Determination of biofilm formation in Congo red agar Candida spp. cultures were incubated in the Congo red agar (CRA) at $35^{\circ} \mathrm{C}$ for $48 \mathrm{~h}$. The isolates forming black colonies were assessed as forming biofilm ${ }^{10}$.

\section{Determination of biofilm formation by microtitra- tion plate method}

After the Candida spp. isolates produced in the SDB were adjusted to be $10^{7} \mathrm{cfu} / \mathrm{mL}$, they were distributed as $20 \mu \mathrm{L}$ in each well of the 96-well plate. $180 \mu \mathrm{L}$ synthetic dextrose liquid (SDL) medium containing 2.5\% glucose was transferred onto it and incubated for $48 \mathrm{~h}$ 
at $35^{\circ} \mathrm{C}$. After incubation, the plates were emptied and each well was washed 3 times with sterile physiological saline. The wells were fixed with $200 \mu \mathrm{L} 99 \%$ methanol for 15 minutes. At the end of this period, the wells were emptied and left to dry. Subsequently, each well was stained with $200 \mu \mathrm{L} \mathrm{2 \%}$ crystal violet for 5 minutes. When this period ended, the wells were washed with distilled water and dried. After the drying, the wells were treated with $160 \mu \mathrm{L} 33 \%$ glacial acetic acid and assessed spectrophotometrically at $570 \mathrm{~nm}$. According to the optical density (OD), biofilm formation was evaluated. If the OD values were $0 \leq \mathrm{OD} 570 \leq 0.120(-), 0.121$ $\leq$ OD $570 \leq 0.240(+), 0.241 \leq$ OD $570 \leq 0.500(++)$ OD570 $\geq 0.500(+++)$, the biofilm was interpreted as negative, weak, intermediate, strong, respectively ${ }^{11}$. The test was carried out in duplicate manner.

\section{Preparation of cell-free filtrate}

Lactic acid bacteria isolates were incubated in MRS broth at $35^{\circ} \mathrm{C} 5 \% \mathrm{CO} 2$ for $48 \mathrm{~h}$. After incubation, the cultures were centrifuged at $10.000 \mathrm{rpm}$ for 10 minutes at $4{ }^{\circ} \mathrm{C}$, supernatant was filtered through a $0.2 \mu \mathrm{m}$ filter.

\section{Determination of the effects of bacterial cells and cell-free filtrate of lactic acid bacteria on the bio- film formation of Candida spp.}

For antibiofilm activity of bacterial cells of lactic acid bacteria, $10 \mu \mathrm{L}$ of the Candida spp. isolates $\left(10^{7} \mathrm{cfu} /\right.$ $\mathrm{mL}$ ) produced in the SDB were distributed into the a 96
- wells plate. $90 \mu \mathrm{L}$ SDB containing $2.5 \%$ glucose was transferred onto it. These wells were incubated at $35^{\circ} \mathrm{C}$ for $48 \mathrm{~h}$ by adding $10 \mu \mathrm{L}$ of bacterial cells of lactic acid bacteria (109 cfu / mL) cultured in the MRS broth and $90 \mu \mathrm{L}$ MRS broth containing of $2.5 \%$ glucose were distributed into the plate. For antibiofilm activity of cellfree filtrate of lactic acid bacteria, $10 \mu \mathrm{L}$ of Candida spp. isolates (107 cfu / mL) cultured in the SDB were distributed into the wells. $140 \mu \mathrm{L}$ SDL containing 2.5\% glucose was transferred onto it. Cell-free filtrate of lactic acid bacteria was added at $50 \mu \mathrm{L}$ and incubated at 35 ${ }^{\circ} \mathrm{C}$ for $48 \mathrm{~h}$. Candida and SDB were added to the wells as control. The amount of biofilm was determined according to the microtitration plate method given above.

\section{Results}

Table I illustrates the hemolytic activity results of yeast isolates isolated from the vagina. Hemolysis was observed in 9 out of 18 Candida strains. In addition, the isolates of C. albicans 24P1, C. albicans 25P1, C. albicans 5MR2, C. albicans 14P1, C. albicans 19P3, C. albicans 27P2, C. tropicalis 1Ç1, C. glabrata 17P2, and C. glabrata 16P did not generate inhibition zone (Table I). While no biofilm formation was observed in C.albicans 19P3 and $C$. tropicalis $1 \mathrm{C} 3$ by the microtitration plate method, high biofilm formation was observed on the Congo red agar. Conversely, high levels of biofilm formation were observed by microtitration plate method in C. tropicalis $1 \mathrm{C} 1$, but it was found there was no biofilm formation on the Congo red agar (Table I).

Table I. Esterase, phospholipase and haemolysis activities and biofilm formations of yeast isolates (MPM: microtitration plate method, CRA: congo red agar)

\begin{tabular}{l|c|c|c|c|c} 
& \multirow{2}{*}{$\begin{array}{c}\text { Esterase } \\
\text { Candivity }\end{array}$} & $\begin{array}{c}\text { Phospholipase } \\
\text { activity }\end{array}$ & Haemolysis & \multicolumn{2}{|c}{ Biofilm } \\
\cline { 5 - 6 } C. albicans 18P1 & + & +++ & + & + & ++ \\
\hline C. albicans 24P1 & - & +++ & - & +++ & +++ \\
\hline C. albicans 30P & + & +++ & + & +++ & ++ \\
\hline C. albicans 15P & + & +++ & + & +++ & ++ \\
\hline C. albicans 25P1 & - & +++ & + & +++ & ++ \\
\hline C. albicans 24P2 & + & ++++ & + & +++ & +++ \\
\hline C. albicans 14P1 & - & ++++ & + & +++ & +++ \\
\hline C. albicans 19 P3 & - & +++ & - & - & +++ \\
\hline C. albicans 27P2 & - & +++ & + & +++ & +++ \\
\hline C. albicans 13P1 & + & +++ & - & + & - \\
\hline C. albicans 8MR11 & + & ++++ & - & +++ & ++ \\
\hline C. albicans 13P2 & + & ++++ & - & + & ++ \\
\hline C. glabrata 17P2 & - & +++ & + & +++ & ++ \\
\hline C. glabrata 16P & - & ++++ & + & +++ & +++ \\
\hline C. glabrata 5MR2 & - & +++ & - & +++ & ++ \\
\hline C. tropicalis 1Ç3 & + & +++ & - & - & +++ \\
\hline C. tropicalis 1Ç1 & - & +++ & - & +++ & - \\
\hline C. tropicalis 29P & + & +++ & - & + & +++ \\
\hline
\end{tabular}


According to results of antifungal activity test against Candida isolates of L. acidophilus 8MR7 and L. paracesei subspecies paracesei $10 \mathrm{MR} 8$ isolates, zone formation observed in 4 of 18 Candida (C. glabrata 16P, $C$. albicans 21P2, C. albicans 24P1, C. albicans 27P2). Zone diameters were recorded between 10-24 mm (Table II).
It was observed that the effect of L. acidophilus $8 \mathrm{MR} 7$ and L. paracasei subspecies paracasei 10MR8 isolates on the biofilm formation of Candida isolates varied according to the isolates. L. acidophilus 8MR7 generally increased the biofilm formation. Biofilm formation in C. albicans 15P, C. albicans 24P1, and C. albicans $14 \mathrm{P} 1$ isolates was recorded lower in comparison to the control.

Table II. Antifungal activities of lactic acid bacteria on Candida spp. isolates. Values are given as mm.

\begin{tabular}{|l|l|l|l|l|}
\hline $\begin{array}{l}\text { Lactic acid bact } \\
\text { eria }\end{array}$ & C. glabrata 16P & $\begin{array}{l}\text { C. albicans 21P } \\
\mathbf{2}\end{array}$ & C. albicans 24P1 & $\begin{array}{l}\text { C. albicans 27P } \\
\mathbf{2}\end{array}$ \\
\hline $\begin{array}{l}\text { L.acidophilus 8M } \\
\text { R7 }\end{array}$ & 12 & 14 & 24 & 12 \\
\hline $\begin{array}{l}\text { L. paracesei } \text { spp. } \\
\text { paracesei 10MR8 }\end{array}$ & 22 & 14 & 20 & 10 \\
\hline
\end{tabular}

It was observed that although bacterial cells of L. paracesei subspecies paracasei $10 \mathrm{MR} 8$ isolate reduced the biofilm formation in other Candida spp. isolates except C. albicans 15P, C. albicans 13P2 C. tropicalis 29P1, and C. tropicalis 1C3 (Figure I), cell-free filtrates of the lactic acid bacteria were more effective on all the Candida spp. isolates (Figure II). Cell-free filtrate of L. acidophilus 8MR7 and L. paracasei subspecies paracasei 10MR8 isolates caused a significant decrease on the biofilm of the Candida spp. isolates.

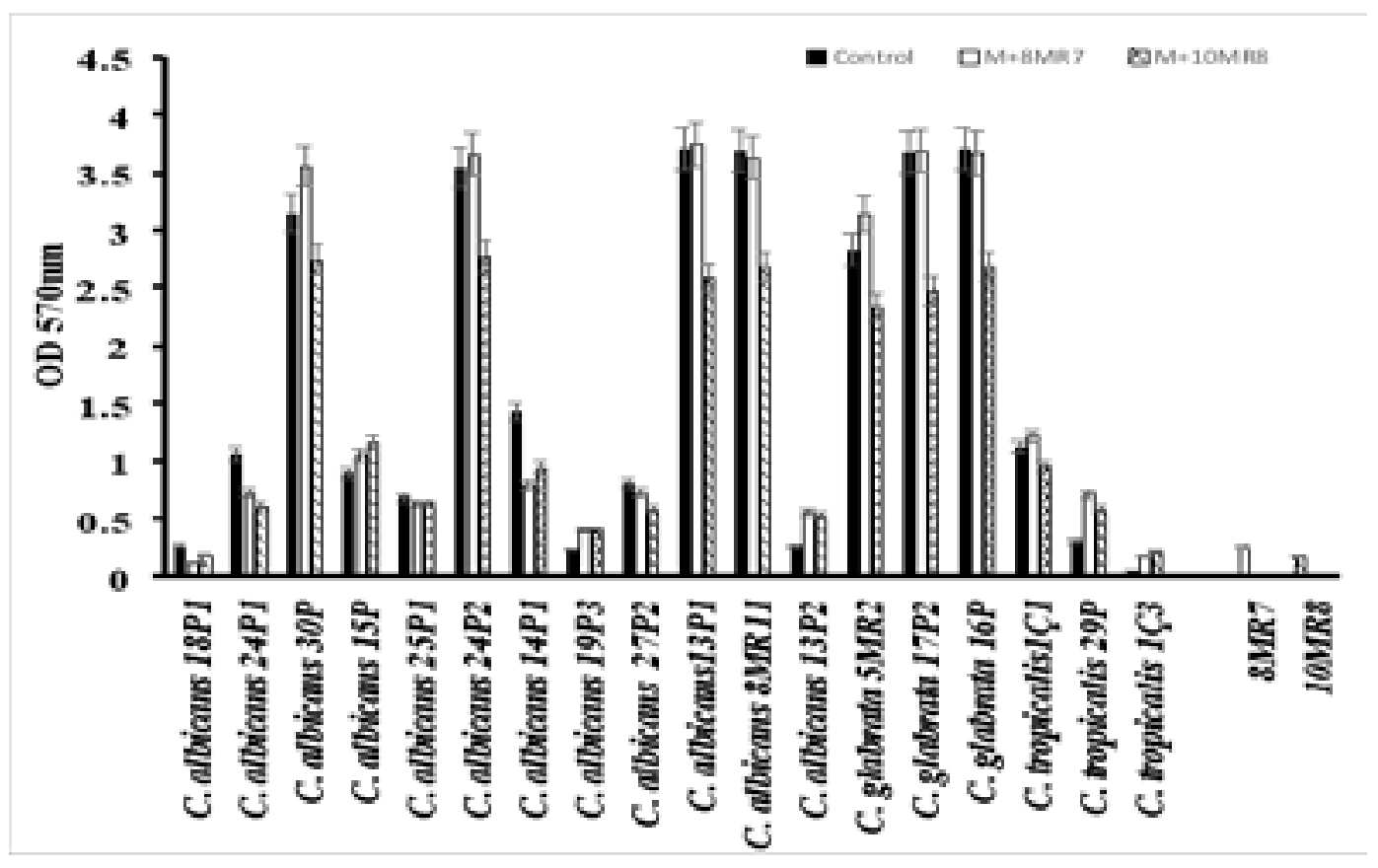

Figure I. Effect of L. acidophilus 8MR7 and L. paracasei spp. paracasei 10MR8 isolates on the biofilm formation of Candida spp. Isolates (M:Candida spp.) 


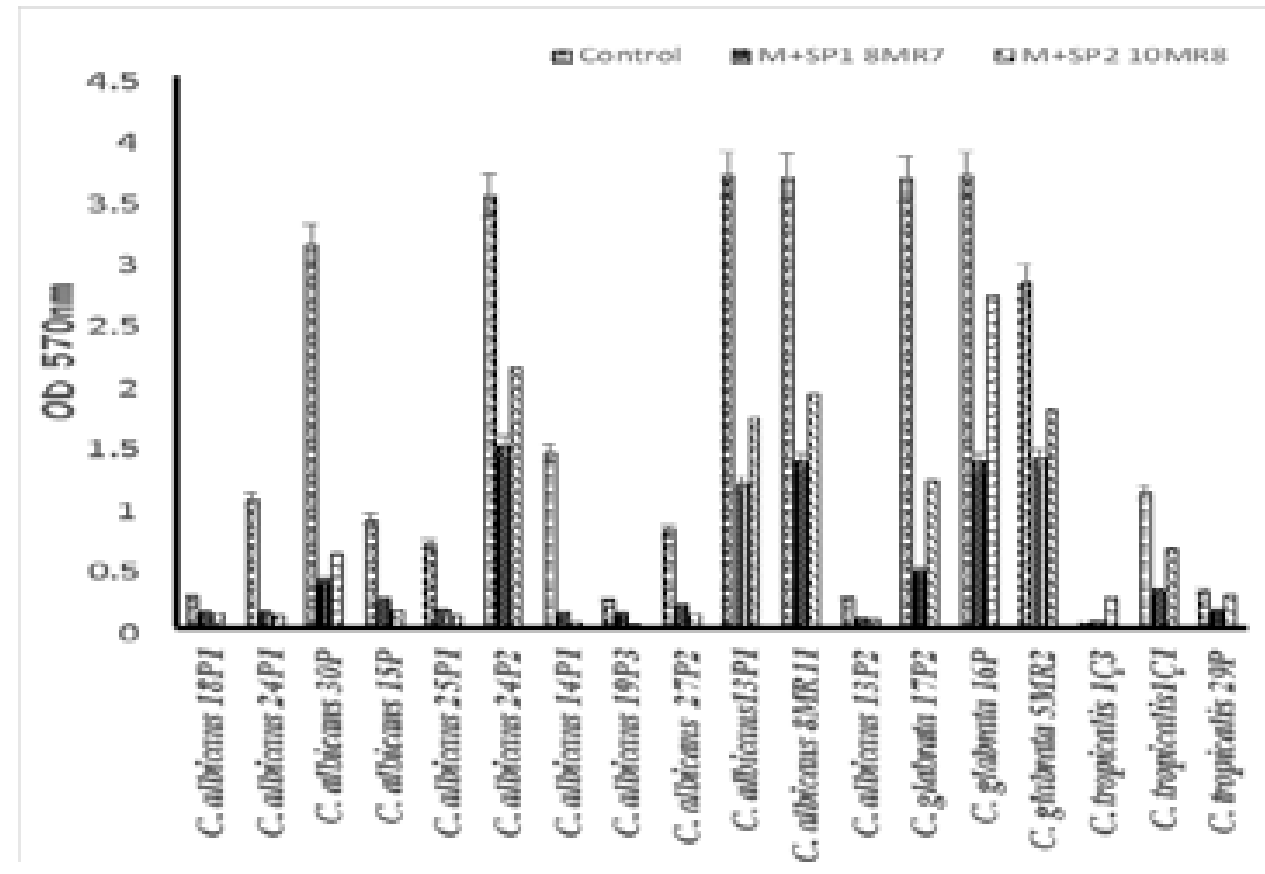

Figure II. Effects of L. acidophilus 8MR7 and L. paracasei spp.paracasei 10MR8 isolates on the biofilm formation of Candida spp. isolates (M: Candida spp., SP1: cell-free filtrate of L. acidophilus 8MR7, SP2: cellfree filtrate of L. paracasei spp. paracasei 10MR8)

\section{Discussion}

The importance of health-friendly bacteria and their products is increasing day by day. In our study, in order to determine the virulence factors of yeast isolates isolated from the vagina, we investigated the hemolysis, esterase, phospholipase activity and biofilm of the isolates. According to the results of hemolytic activity of yeast isolates, hemolysis was observed in nine isolates (C. albicans 18P1, C. albicans 30P, C. albicans 15P, C. albicans 25P1, C. albicans 24P2, C. albicans 14P1, C. albicans 27P2, C. glabrata 17P2, and C. glabrata 16P). In a study conducted by Luo et al., it was revealed that $C$. albicans, C. glabrata, and C. tropicalis isolates isolated from human had alpha hemolytic activity6. In another study, it was reported that 4 of the 63 C. albicans isolates had alpha hemolysis, 53 had alpha + beta hemolysis, 6 did not have hemolysis and 2 C. tropicalis isolates did not have hemolytic activity12. All of our Candida spp. isolates had high phospholipase activity. It was found that while 7 of the C. albicans strains (C. albicans 18P1, C. albicans 30P, C. albicans 15P, C. albicans 24P2, C. albicans 13P1, C. albicans 18MR11, and C. albicans 13P2), and two of the C. tropicalis strains (C. tropicalis 1Ç3, C. tropicalis 1Ç1) had esterase activity, none of $C$. glabrata strains had esterase activity. It was revealed that most of the pathogenic Candida species released some lipolytic enzymes such as esterase and phospholipases ${ }^{7}$. It was also reported that phospholipases were highly likely to increase the pathogenicity of $C$. albicans. Gültekin et al. ${ }^{13}$ reported that C. albicans strains had phospholipase activity, but this activity was not available in non-albicans species. Phospholipase activity was detected in $73 \%$ of vaginal discharge samples ${ }^{13}$. Gültekin et al. ${ }^{14}$ reported that none of the 65 vaginal isolates (C. glabrata) had esterase and phospholipase activity; only two of the isolates produced biofilm ${ }^{14}$.

The formation of biofilm was changed according to the strains. It was observed that there were some differences between the two methods. However, it was found that biofilm formation was generally high. Cevahir et al. reported that 14 of the 34 Candida spp. isolated from the vagina were positive for Congo red agar ${ }^{15}$. It was found that all of the18 isolates were positive for Congo red agar. It was reported that $48 \%$ of 33 Candida spp. isolates isolated from vaginal discharge samples produced biofilm, and this proportion in C.albicans was $63 \%{ }^{16}$. Silva et al. reported that Candida spp. isolates isolated from the vagina, as in our study, produced high levels of biofilms ${ }^{17}$. Gültekin et al. reported that none of the 65 vaginal isolates (C. glabrata) had esterase and phospholipase activity; only two of the isolates produced biofilm13. Kuzucu et al. reported that 16 (48\%) of the 33 C. albicans isolates they isolated from the vaginal discharge samples produced biofilms ${ }^{16}$. Paiva et al. reported that $C$. tropicalis produced high levels of biofilm. They reported that C.parapsilosis, C. psendotropicalis, and $C$. glabrata produced less biofilm than pathogenic C. albicans $^{18}$. 
L. acidophilus 8MR7 and L. paracasei subspecies paracasei $10 \mathrm{MR} 8$ isolates had inhibitory activity in only 4 of the 18 Candida spp. isolates. 3 of these isolates were $C$. albicans and 1 was $C$. glabrata. No inhibitory effect on other isolates was observed. Ström et al. demonstrated that various antifungal compounds such as cyclic dipeptides, pyroglutamic acid and lactone had an important effect on the Candida species19. In a similar study, $L$. acidophilus and $L$. plantarum isolated from vagina proved antifungal activity against pathogenic Candida species ${ }^{20}$. Lactobacillus species intensively colonize the vaginal epithelium and control the vaginal microflora. Lactic acid bacteria in the vagina, lactic acid and bacteriocin, antimicrobials such as hydrogen peroxide, protect vaginas against the pathogens. The lactic acid bacteria in the vagina provides vaginal homeostasis by producing organic acids such as lactic acid. With lactic acid production, vaginal $\mathrm{pH}$ is kept below 4.5. Thus, at this $\mathrm{pH}$ the development of pathogens is prevented ${ }^{21}$. The antibiofilm activity of $L$. acidophilus 8MR7 and L. paracasei subspecies paracasei 10MR8 isolates regarding the biofilm formation against Candida spp. isolates varied according to the isolates. The production of biofilms by C. albicans 15P, C. albicans 24P1, and C. albicans $14 \mathrm{P} 1$ isolates was lower in comparison to the control group. L. paracasei subspecies paracasei 10MR 8 decreased the formation of biofilm except the C. albicans 15P, C. albicans 13P2, C. tropicalis 29P1, and C. tropicalis 1C3 (Figure I). The lactic acid bacteria found in the vagina compete with the C. albicans for the adhesion zones and may inhibit biofilm formation by inhibiting the adhesion of $C$. albicans. In addition the organic acids such as lactic acid and hydrogen peroxide secreted by lactic acid bacteria inhibit the growth of $C$. albicans. In this way they can prevent the diseases caused by $C$. albicans ${ }^{3}$. Gudiña et al. reported that the ability of $L$. acidophilus and $L$. paracasei subspecies paracasei A20 to inhibit the adhesion of Candida species was low 22 . Their findings are consistent with our data. The cell-free filtrates of $L$. acidophilus $8 \mathrm{MR} 7$ and L. paracasei subspecies paracasei 10MR8 inhibited the formation of biofilms of the Candida spp. strains. Bulgasem et al. reported that the formation of C. glabrata ATCC 2001 and C. albicans ATCC 14053 biofilm on the platelets previously coated with Lactobacillus curvatus $\mathrm{HH}$ was significantly inhibited ${ }^{23}$. They also reported that L. curvatus $\mathrm{HH}$ supernatant significantly reduced the biofilm formation of C. albicans, C. krusei, and C. glabrata, and L. plantarum HS supernatant significantly reduced the biofilm formation of C. glabrata and C. krusei ${ }^{23}$.
Fracchia et al. and Zakaria reported that the lactic acid bacteria producing bio surfactants had high anti-adhesion capacity against the pathogenic $C$. albicans ${ }^{24,25}$. The researcher suggested that the anti-adhesion properties of lactic acid bacteria might be due to the bio surfactant in the filtrate. Similar findings were also emphasized by Gudiña et al. Zeraik et al. reported that the anti-adhesion effect of lactic acid bacteria filtrate varied according to the properties of supernatant, test microorganism and surface properties ${ }^{22,26}$. They report that when the surface was covered with filtrate containing biosurfactant, the surface became hydrophilic and reduced microbial adhesion ${ }^{26,27}$. In our study, the fact that supernatants of L. acidophilus 8MR7 and L. paracasei subspecies paracasei $10 \mathrm{MR} 8$ were more effective might be to do with bio surfactant production.

The inhibition of surface adhesion of pathogenic bacteria to filtrates of the lactic acid bacteria is of great importance for health. This may also be important for biomedical instruments. Falagas and Makris emphasized that the bio surfactants isolated from Lactobacillus might play an important role in inhibiting adhesion in the maintenance equipment such as catheters and other medical devices used in hospitals ${ }^{28}$.

\section{Conclusion}

While the main mechanism of lactic acid bacteria to inhibit biofilm formation of Candida species is the competition in the adhesion zone, the materials contained in the cell-free filtrates of lactic acid bacteria are important as well. When we look at the cell-free filtrates of $L$. acidophilus 8MR7 and L. paracasei subspecies paracasei 10MR8 isolates, it is seen that they have a significant anti-adhesion activity. These isolates are promising as potential bacteria that can be used for anti-adhesion purposes in materials used in healthcare, as well as especially as the support for the health of the vagina.

\section{Acknowledgements}

This work was supported by a grant from the Anadolu of University and Research, within the research project 1305F089 / 2016.

\section{Conflict of interest}

The authors declare that they have no conflicts of interest.

\section{Ethical approval}

This study was approved by Istanbul Medipol Universi- 
ty Non-Interventional Clinical Researches Ethics Board on 11/04/2013 with decision number38. All applicable international, national, and/ or institutional guidelines for the care and use of human were followed.

\section{References}

1. Fettweis JM, Serrano MG, Girerd PH, Jefferson KK, Buck GA. A New Era of the Vaginal Microbiome: Advances Using Next-Generation Sequencing. Chem Biodivers. 2012; 9: 965 - 976.

2. Mårdh PA. The vaginal ecosystem. Am J Obstet Gynecol. 1991; 165: 1163-68.

3. Rönnqvist D, Forsgren-Brusk U, Husmark U, Grahn-Håkansson E. Lactobacillus fermentum Ess-1 with unique growth inhibition of vulvo-vaginal candidiasis pathogens. J Med Microbiol. 2007; 56: 1500-1504.

4. Salminen S, Ouwehand AC, Isolauri E. Clinical applications of probiotic bacteria. Int Dairy Journal. 1998; 8: 563-572.

5. Li S, Zhao Y, Zhang L, Zhang X, Huang L, Li D, et al. Antioxidant activity of Lactobacillus plantarum strains isolated from traditional Chinese fermented foods. Food Chem. 2012; 135: 1914-9.

6. Luo G, Samaranayake LP, Yau JYY. Candida Species Exhibit Differential In Vitro Hemolytic Activities. J Clin Microbiol. 2001; 39(8): 2971-74.

7. Slifkin M. Tween 80 opacity test responses of various Candida species. J Clin Microbiol. 2000; 38(12): 46264628.

8. Borstt A, Fluit AC. High levels of hydrolytic enzymes secreted by Candida albicans isolates involved in respiratory Infections. J Med Microbiol. 2003; 52: 971-4.

9. Pascual LM, Daniele MB, Ruiz F, Giordano W, Pajaro C, Barberis L. Lactobacillus rhamnosus L60, a potential probiotic isolated from the human vagina. $J$ Gen Appl Microbiol. 2008; 54: 141-148.

10. Kaiser TDL, Pereira E M, Dos Santos KRN, Maciel ELN, Schuenck RP, Nunes APF. Modification of the Congo red agar method to detect biofilm production by Staphylococcus epidermidis. Diagnostic Microbiol Infect Dis. 2013; 75(3): 235-239.

11. Stepanovic S, Vukovic D, Dakic I, Savic B, Svabic-Vlahovic M. A modified microtiter-plate test for quantification of staphylococcal biofilm formation. $J$ Microbiol Methods. 2000; 40, 175-179.

12. Özekinci T, Akpolat N, Mete M, Atmaca S. Candida Türlerinin In Vitro Hemolitik Aktivitesi. Turk I Infect. 2007; 21(4): 201-203.

13. Gültekin B, Eyigör, M, Tiryaki Y, Kırdar S, Aydin N. Kan Kültürlerinden İzole Edilen Candida Suşlarında Antifungal Duyarlılığın ve Bazı Virülans Faktörlerinin
Araştırılması ve RAPD-PCR ile Genotiplendirilmesi. Mikrobiyol Bul. 2011; 45(2): 306-317.

14. Gültekin B, Tiryaki Y, Aydın N. Klinik Örneklerden İzole Edilen Candida glabrata Suşlarında Salgısal Asit Proteinaz, Fosfolipaz, Esteraz Aktivitelerinin ve Biyofilm Oluşumunun Araştırılması. Türk Mikerobiyol Cem Derg. 2013; 43(1):17-21.

15.Cevahir N, Demir M, Mete E, Kaleli İ. Candida suşlarında farklı yöntemlerle slime üretiminin araştırılmas1. Infeksiyon Derg. 2003; 17: 67-70.

16. Kuzucu Ç, Çizmeci Z, Durmaz B. Candida türlerinde biyofilm ve fosfolipaz aktivitesinin saptanmas1. Türk Hij Den Biyol Derg. 2003; 60(3): 73-76.

17. Silva S, Henriques M, Martins A, Oliveria R, Williams D, Azeredo J. Biofilms of non-Candida albicans Candida species: quantification, structure and matrix composition. Med Mycol. 2009; 47: 681-689.

18. Paiva LCF, Pedrina GV, Donatti L, Svidzinki TIE, Consolara MEL. Assessment of in vitro biofilm formation by Candida species isolates from vulvovaginal candidiasis and ultrastructural characteristics. Micron. 2012; 43(2): 497-502.

19. Ström K, Sjögren J, Broberg A, Schnürer J. Lactobacillus plantarum MiLAB 393 produces the antifungal cyclic dipeptides cyclo (L-Phe-L-Pro) and cyclo (L-Phetrans-4-OH-L-Pro) and 3-phenyllactic acid. Appl Environ Microbiol. 2002; 68: 4322-4327.

20. Ogunshe AA, Omotoso MA, Bello VB. The in vitro antimicrobial activities of metabolites from lactobacillus strains on Candida species implicated in Candida vaginitis. Malays J Med Sci. 2011; 18: 13-25.

21. Cheeti S, Warrier BK, Lee CH. The role of monocarboxylate transporters in uptake of lactic acid in HeLa cells. Int J Pharm. 2006; 325: 48-54.

22. Gudiña EJ, Rocha V, Teixeira JA, Rodrigues LR. Antimicrobial and antiadhesive properties of a biosurfactant isolated from Lactobacillus paracasei ssp. paracasei A20. Lett Appl Microbiol. 2010; 50: 419-424.

23. Bulgasem BY, Hassan Z, Abdalsadiq NKA, Yusoff WMW, Musa EMMT, Lani MN. Anti-Adhesion Activity of Lactic Acid Bacteria Supernatant against Human Pathogenic Candida Species Biofilm. Health Science J. 2015; 9(6): 1-7.

24. Fracchia L, Cavallo M, Allegrone G, Martinotti M. A Lactobacillus-derived biosurfactant inhibits biofilm formation of human pathogenic Candida albicans biofilm producers. Appl Microbiol Biotechnol. 2010; 2: 827-837

25. Zakaria Gomaa E. Antimicrobial and anti-adhesive properties of biosurfactant produced by lactobacilli isolates, biofilm formation and aggregation ability. J Gen Appl Microbiol. 2013; 59: 425-436. 
26. Zeraik AE, Nitschke M. Biosurfactants as agents to reduce adhesion of pathogenic bacteria to polystyrene surfaces: effect of temperature and hydrophobicity. Curr Microbiol. 2010; 61: 554-559.

27. Gudiña EJ, Teixeira JA, Rodrigues LR. Isolation and functional characterization of a biosurfactant pro- duced by Lactobacillus paracasei. Colloids Surf B Biointerfaces. 2010b; 76: 298-304.

28. Falagas ME, Makris GC. Probiotic bacteria and biosurfactants for nosocomial infection control: a hypothesis. J Hosp Infect. 2009; 71: 301-306. 